\title{
Observation and thinking of Innovative Courses in Colleges and Universities
}

\author{
$\mathrm{Li} \mathrm{Li}^{1}$, Tingting $\mathrm{Zou}^{1}$, Bin Liu ${ }^{1}$, Lei $\mathrm{Wu}^{*}{ }^{1}$ and Helang Huang ${ }^{*}, 1$ \\ ${ }^{1}$ School of Public Health and Jiangxi Province Key Laboratory of Preventive Medicine, Nanchang University, \\ Nanchang, Jiangxi, P.R. China \\ *Corresponding author. Email: wulei2060@aliyun.com \\ Li Li and Tingting Zou are co-authors. \\ Lei $W u$ and Helang Huang are co-corresponding authors.
}

\begin{abstract}
The courses of innovation and entrepreneurship training are proposed by colleges and universities to change the traditional education concepts and cultivate more applied talents. This article takes Nanchang University as an example to introduce the current situation and existing problems of innovative courses in universities. Aiming at these problems, the author puts forward some relevant suggestions from the perspective of teachers and schools in order to improve the teaching quality of innovative courses and explore the educational methods of college students' innovation and entrepreneurship.
\end{abstract}

Keywords: Innovative courses, Teaching method, Educational innovation, Higher education.

\section{INTRODUCTION}

The cultivation of college students' innovation and entrepreneurship ability is the focus of the education and teaching reform in colleges and universities. How to improve the innovation and entrepreneurship ability of college students to meet the needs of the country for talent training is the core issue of common concern for education management departments, education departments and college students. In 2011, the Ministry of Education of the People's Republic of China has launched innovation and entrepreneurship courses (commonly called innovative courses) for college students [1], with the purpose of changing the educational ideology, reforming the training model, and cultivating high-quality innovative talents with comprehensive development. Subsequently, universities in various places have successively launched various innovative courses. Although the process is not smooth, they have achieved good results in general, which are extremely beneficial to the development of students [2].

\section{THE SITUATION AND MAIN ACHIEVEMENTS OF INNOVATION COURSES}

The characteristics of the innovative courses are reflected in innovation, creativity and practicality [3]. The teaching process generally consists of students participating in innovation training projects individually or in teams, and then completing research project design, research condition preparation and project implementation independently under the guidance of teachers. The positive role of innovative courses cannot be ignored, especially in stimulating medical students' enthusiasm for scientific research and cultivating innovative thinking abilities [4]. Nanchang University has the good tradition and culture of innovation and entrepreneurship education. In 2018, the school won a total of 394 innovation awards above the provincial level, and was named one of the first batch of "50 universities" with typical innovation and entrepreneurship experience in the country. Under the call of relevant departments, leaders of the school have established a strong awareness of innovative teaching and constructed a series of systems and measures to ensure the smooth development of the courses. These measures which include setting up special innovation and entrepreneurship colleges, perfecting the training 
programs and requiring each student to take 2 credits of innovative courses have created good atmosphere for teaching and learning of innovative courses in whole school. Moreover, the variety of innovative courses is growing rapidly, which gives students more choices to find out what they are interested in [5]. What is more important is that the diversity of teaching forms reflecting good innovation and practicality. Current studies have shown that there are few innovative studies related to university health education courses [6]. But "Knowledge and Skills of First Aid" taught by professor Liping Zhang has created a high-quality course under the multi-dimensional Internet which reflects the advantages of combining simulation training with virtual simulation. This course is not only aimed at students but also the general community residents, which becoming a typical portrayal of knowledge directly serving the society. In addition, Probiotics Food Research and Development Training taught by researcher Xiaohua Liu whose teaching process always focuses on the cultivation of operation and hands-on ability, during which students not only master the skills but also feel interested and pleasure. The "MCM Competition Questions Explanation" and other mathematical model courses taught by Professor Tao Chen from the School of Science combine traditional and modern teaching methods to train students how to build the best mathematical model based on realistic conditions and the environment. At the same time, the teachers of this course organized and guided students to participate in a series of competitions and have won more than 100 awards in the past ten years. Students believe that this type of innovative course can not only significantly improve their abstract thinking, logical thinking and problem-solving skills, but also cultivate their sense of competition and teamwork spirit. These successful experiences set an example for the development of other innovative courses.

\section{SOME SHORTAGES IN THE CONSTRUCTION AND TEACHING OF INNOVATIVE COURSES}

Although the innovation courses have achieved good results, there are some shortcomings or deficiencies that cannot be ignored. Firstly, the development of innovation courses which overemphasizes the quantity of courses but ignores the importance of the unification of quantity and quality [7]. It simply increases the number of courses that do not have the attributes and elements of innovation or creation and the spirit of independence because some teachers and students fail to grasp the connotation of innovative courses. Furthermore, some courses are utilitarian and perfunctory that some directly copied or edited other research projects or achievements or just pieced together from the Internet and books aim at awarding in "Challenge Cup" National College Student Business Plan Competition. Secondly, the lecturers who only taught pure theoretical knowledge did not combine the course with the practical experience related to innovation and entrepreneurship. What's more, some teachers themselves lack the practical experience and perception of innovation and entrepreneurship as well as the observation and analysis of enterprises and markets. Even some teachers with rich experience in scientific research also fail to connect their own vivid scientific research cases in teaching. Thirdly, some teachers lack the art of teaching who do not have in-depth understanding of educational theories and methods and fail to grasp the rules of teaching [8]. As is known to all, students participating in innovative courses have different academic backgrounds, which leads to great differences in their basic knowledge. Therefore, teachers should flexibly change teaching methods according to different objects to unify the content and form so that most students can understand the main content of the class. In terms of teaching content and form, some teachers like to play relevant video in class. The problem with this approach is not the teaching style, but the teacher's failure to use the video to help students summarize and refine relevant knowledge. For example, when teaching Entrepreneurship, the teacher played a video about Bill Gates' entrepreneurial process, but did not deeply explore his entrepreneurial spirit, good thinking habits, sense of social responsibility and other advantages to inspire students. The Fourth, a small number of teachers who stop and adjust courses at will or shorten and change teaching content and class time without permission. For example, the Clinical Diagnostic Auxiliary Skills Course was scheduled for 11 weeks, but the teacher shortens it to 8 weeks at random to complete all the teaching tasks. In some cases, the advisors even have not met with the students from the beginning to the end of the projects.

It seems that there are many problems in the innovation course, we should attach great importance to it and put forward measures to improve the situation.

\section{THE SUGGESTIONS FOR IMPROVING THE INNOVATION COURSE}

First of all, schools should focus on the quality of innovative courses rather than quantity [9]. It is better for schools to conduct a comprehensive evaluation of the courses already opened, summarize experience and analyze problems according to the evaluation results with the aim of adjusting innovative courses and improving the quality of courses. For example, the school organizes experts to evaluate the innovative courses from the aspects of consciousness cultivation, 
ability improvement and practice simulation so as to eliminate unqualified courses and create high-quality courses. Schools should strengthen management at the same time, from the curriculum setting and declaration, approval and implementation, evaluation and assessment and other links to develop effective incentive and elimination mechanism for making the innovative curriculum teaching truly innovative, practical and standardized. Secondly, the schools should select and strongly advocate the teachers with strong sense of innovation and rich experiences in scientific research and entrepreneurship. Because innovation and entrepreneurship are not theoretic, the formation of innovation consciousness is from practice, observation, accumulation and feelings of long-term work and life. For example, those teachers' teaching contents about which have part-time experiences in relevant enterprises will be more vivid and more fully integrated with practices. This is in sharp contrast to those who only teach textbook knowledge but have no experience in practice and scientific research. Thirdly, teachers should correctly understand the essence of innovative courses and attach importance to the cultivation of teaching art [10]. Although some teachers have a rich theoretical, technical foundation and a strong sense of responsibility for teaching, they failed to deeply understand connotations and real purposes of innovative teaching. In addition to the imparting of knowledge and skills, innovation courses are more important to enlightening students' innovation consciousness, entrepreneurship and cultivating their humanistic qualities in the process of creation. At the same time, free learning environment, exploration and learning interests and rare opportunities and the appropriate imitation and so on are also noticeable influence on innovation course. For example, the system environments of the National Nature Science Foundation of China are freedom and fair which inspired the creativity of numerous scientific research workers in our country. In addition, it is well known that the emergence of Internet technology has brought opportunities for Alibaba of Jack Ma. Therefore, as teachers of innovation course, they should fully realize that the wide space and importance of innovative thinking and methods, and actively participate in the learning and training of teaching methods and arts. Fourthly, the schools set up teaching supervision groups to check the teaching situation of teachers [11]. Teachers will take teaching tasks more seriously because of the teaching inspection. In addition, teachers should have interactions with students regularly so as to summarize their experiences and improve their work.

\section{CONCLUSION}

There has been a significant increase in the number and types of innovative courses offered in colleges and universities that more and more and more students are actively participating. However, the teaching quality of innovative courses still needs to be improved. Teachers should combine their innovative practical experiences with the courses and pay more attention to teaching methods. Meanwhile, schools should also improve the evaluation system of innovative courses to select high-quality innovative courses. Only in this way can the transformation from quantity to high quality of innovative courses be completed.

\section{ACKNOWLEDGMENT}

This article is in the Teaching research project "Key Projects of Teaching Reform Research in Colleges and Universities in Jiangxi Province" (NO. JXJG-16-1-7).

\section{REFERENCES}

[1] Xu Hudi, Wang Rui, Yang Liu, et al. Investigation and Research on College Students' Participation in Innovation Training Project[J]. China Higher Medical Education, 2019(1).

[2] Zhang Xiujun. Study on Reform of Teaching Model of Innovative Curriculum [J]. Journal of Linyi Teachers' College, 2009(05):30-33.

[3] Adams M E. Promoting Diversity in College Classrooms: Innovative Responses for the Curriculum, Faculty, and Institutions $[\mathrm{J}]$. New Directions for Teaching \& Learning, 2010:152.

[4] Macrae K. Enhancing Student Employability: Innovative Projects from across the Curriculum [J]. 2006.

[5] Huang Jizhi, Wu Lei, Huang Helang, et al. Discussion the Exterior Restricting factor and Converted Strategy of Reform of Higher Medical Education in China[J]. Northwest Medical Education, 2009,17(16).

[6] Sadeghi R, Heshmati H. Innovative methods in teaching college health education course: A systematic review. J Educ Health Promot. 2019; $8: 103$.

[7] Derry S J, Levin J R, Osana H P, et al. Fostering Students' Statistical and Scientific Thinking: Lessons Learned From an Innovative College Course [J]. American Educational Research Journal, 2000, 37(3):747-773. 
[8] Qiu Chunlin, Yu Hongyan. Rethinking of Innovative Curriculum Design [J]. China Adult Education, 2009(15):112-113.

[9] Lin Jian, Fu Hanguang, Wu Zhongwei, et al. The Teaching and Experience of Practical Innovation Course in Colleges and Universities [J]. Theory and Practice of Contemporary Educational, 2010(06):74-76.
[10] Wu Keyan, Cai Jie. The Exploration of Setting Up Innovative Courses in Colleges and Universities [J]. China Adult Education, 2010(11):135-136.

[11] Nagyová, Adriana, Pisoňová, Mária, Tóblová, Eva. The Research and Analysis within The Innovation of School Management Course [J]. Procedia Social and Behavioral Sciences, 2015, 186:1169-1173. 